\title{
PENGARUH APLIKASI PSEUDOMONAS FLUORESCENS P60 TERHADAP MUTU PATOLOGIS, MUTU FISIOLOGIS, DAN PERTUMBUHAN BIBIT PADI IR 64
}

\author{
Lisa Navitasari ${ }^{1}$, Loekas Soesanto ${ }^{2}$, \& Ahadiyat Yugi Rahayu ${ }^{2}$ \\ ${ }^{1}$ STTP Malang, Kementerian Pertanian \\ ${ }^{2}$ Program Studi Agronomi, Program Pascasarjana, Universitas Jenderal Soedirman Purwokerto \\ E-mail: lissa_nav@yahoo.com
}

\begin{abstract}
Effect of Pseudomonas fluorescens P60 on pathological and physiological quality and growth of rice IR 64 seedlings. The research objectives were (1) detection and identification of seed-borne pathogens of IR 64 rice, (2) testing Pseudomonas fluorescents $\mathrm{P} 60$ in inhibiting the in vitro growth of seed-borne pathogens colonies, (3) testing P. fluorescents P60 for pathological and physiological seed quality, and (4) testing P. fluorescents P60 on the growth of seedlings in the greenhouse. The results showed that some seed-borne pathogens can be found both on farmers' IR 64 rice and factory's; they were Aspergillus flavus, Alternaria padwickii, Pseudomonas glumae, and P. syringae. Application of $P$. flourescens $\mathrm{P} 60$ was able to inhibit the in vitrogrowth of colonies of all seed-borne pathogens, except $P$. syringae. Related to pathological quality, the effect of $P$. flourescens $\mathrm{P} 60$ on percentage of seed-borne pathogens attack did not significantly different from that of benomil but smaller than distilled water. On the physiological quality of seeds, treatment of $P$. flourescens P60 has the same effect with benomil and distilled water, with germination rate was more than $80 \%$. In the greenhouse study,treatment of seed immersion time in P. flourescens P60 suspension showed that the effect of immersion time as long as 15 minutes and 25 minutes on seedling height, root length, and seedling dry weightdid not significantly different. were. However, 25 minutes immersion time resulted in fresh seedling weight and root dry weight higher than that of 15 minutes immersion time.
\end{abstract}

Key words: growth of seedlings, pathological and physiological seed quality, Pseudomonas flourescens P60, seedborne pathogen

\section{ABSTRAK}

Pengaruh aplikasi Pseudomonas fluorescens P60 terhadap mutu patologis, mutu fisiologis, dan pertumbuhan bibit padi IR 64. Penelitian bertujuan (1) mendeteksi dan mengidentifikasi patogen tular-benih padi IR 64, (2) menguji pengaruh $P$. flourescens $\mathrm{P} 60$ dalam menghambat pertumbuhan koloni patogen tular-benih secara in vitro, (3) menguji pengaruh Pseudomonas flourescens $\mathrm{P} 60$ terhadap mutu patologis dan fisiologis benih, dan (4) menguji pengaruh $P$. flourescens $\mathrm{P} 60$ terhadap pertumbuhan bibit padi di rumah kaca. Hasil penelitian menunjukkan bahwa beberapa patogen tular-benih dapat ditemukan baik pada padi IR 64 dari petani maupun dari pabrik;yaitu Aspergillus flavus, Alternaria padwickii, Pseudomonas glumae, dan P. syringae. Aplikasi $P$. flourescens P60 mampu menghambat pertumbuhan koloni semua patogen tular-benih secara in vitro, kecuali $P$. syringae. Pengaruh $P$. flourescens P60 terhadap mutu patologis benih menunjukkan bahwa persentase serangan patogen tular-benih tidak berbeda nyata dengan persentase serangan patogen tular-benihpada perlakuan benomil tetapi lebih kecil dari pada akuades. Terhadap mutu fisiologis benih, perlakuan P. flourescens P60 memiliki pengaruh yang sama dengan benomil dan akuades, dengan daya kecambah di atas $80 \%$. Hasil pengujian di rumah kaca menunjukkan bahwa perlakuan lamaperendaman benih padi dalam suspensi P. flourescens P60 dengan waktu perendaman 15 menit dan 25 menit memiliki pengaruh yang tidak berbeeda nyata terhadap tinggi bibit, panjang akar, dan bobot kering bibit . Akan tetapi, waktu perendaman selama 25 menit menghasilkan berat basah bibit dan bobot kering bibit yang lebih tinggi dari pada waktu perendaman selama 15 menit.

Kata kunci: fisiologi pertumbuhan bibit, mutu patologis, patogen tular benih, Pseudomonas flourescens $\mathrm{P} 60$

\section{PENDAHULUAN}

Varietas benih padi yang masih dipakai dan disukai petani adalah IR 64 (Hadi et al., 2005). Namun, ketersedian benih unggul masih menjadi suatu kendala, diantaranya mutu benih yang masih rendah, baik mutu patologis dan fisiologis benih. Salah satu penyebab rendahnya mutu patologis adalah patogen tular-benih, yang mengakibatkan rendahnya mutu fisiologis benih, diantaranya benih gagal berkecambah dan pertumbuhan 
kecambah tidak normal (Agarwal \& James, 2000; Sutopo, 1993), sehingga mengakibatkan perlunya perlakuan benih.

Perlakuan benih secara umum dilakukan secara fisik dan kimia. Perlakuan benih secara fisik antara lain merendam benih sebelum tanam, sedangkan perlakuan benih secara kimia menggunakan bahan kimia, seperti gas metil bromida, fosfin, senyawa merkuri florida, cairan merkuri organik, dan fungisida lainnya (Agarwal \& James, 2000). Penggunaan bahan kimia sintetis dalam perlakuan benih mengakibatkan penurunan kegigasan benih dan memperpendek masa hidup benih, sehingga perlu alternatif lain dalam perlakuan benih, salah satunya dengan memanfaatkan agensia hayati yang bersifat antifungi dan antibakteri yaitu Pseudomonas flourescens P60. P. flourescens P60 merupakan agensia hayati yang diisolasi dari perakaran tanaman gandum (Soesanto et al., 2011) dan banyak digunakan sebagai pengendalian hayati patogen tular-tanah (Santoso et al., 2007). Namun, potensi P. flourescens P60 belum pernah digunakan dalam perlakuan benih untuk menekan adanya patogen tular-benih. Tujuan penelitian ini adalah (1) mendeteksi dan mengidentifikasi patogen tular-benih Padi IR 64 dari petani dan IR 64 dari pabrik, (2) menguji Pseudomonas flourescens P60 dalam menghambat pertumbuhan koloni patogen tularbenih in vitro, (3) menguji Pseudomonas flourescens P60 terhadap mutu patologis dan fisiologis benih, (4) menguji Pseudomonas flourescens P60 terhadap pertumbuhan bibit padi di rumah kaca.

\section{METODE PENELITIAN}

Tempat dan Waktu. Penelitian dilaksanakan di Pusat Pengembangan dan Pemberdayan Pendidik dan Tenaga Kependidikan (PPPPTK) Pertanian Cianjur, Universitas Jenderal Soedirman (UNSOED) Purwokerto, dan Pusat Penelitian Biologi-LIPI, Cibinong, pada bulan September 2012-Maret 2013

Deteksi dan identifikasi patogen tular-benih dan penyiapan inokulum. Patogen tular-benih dideteksi dengan metode blotter test. Benih ditumbuhkan dalam cawan Petri yang dialasi kertas stensil basah. Benih diinkubasi pada suhu ruang dengan penyinaran NUV selama 12 jam terang dan 12 jam gelap secara bergantian, selanjutnya selama 24 jam pada suhu -20 ${ }^{0} \mathrm{C}$. Pada hari ketiga, benih kembali diinkubasi pada suhu ruang di bawah penyinaran NUV 12 jam terang dan 12 jam gelap secara bergantian sampai hari ketujuh (ISTA, 2008). Pada hari kedelapan, diamati dan diidentifikasi patogen dengan kunci identifikasi pictorial atlas (Watanabe, 1994), dihitung persentase tingkat serangan patogen dengan rumus:

Persentaseserangan $=\frac{\sum \text { benih terinfeksi }}{\sum \text { benih total }} \times 100 \%$

dan isolasi patogen dengan teknik isolasi spora tunggal (Turechek \& Stevenson, 1998).

Pengujian P. flourescens P60 dalam menghambat pertumbuhan koloni patogen tular-benih in vitro. Inokulum diletakkan dengan jarak $3 \mathrm{~cm}$ dari tepi cawan Petri dan P. flourescens (kerapatan $10^{9} \mathrm{upk} / \mathrm{ml}$ ) digoreskan memanjang dengan jarak $3 \mathrm{~cm}$ dari tepi cawan Petri berlawanan arah dengan letak patogen, diinkubasikan dalam suhu $26-28^{\circ} \mathrm{C}$ selama 5 hari, dihitung persentase daya hambat (DH) (Ezra et al., 2004; Astuti, 2008), sementara untuk pengujian terhadap patogen bakteri, dilakukan dengan cara menambahkan $6 \mathrm{ml}$ air steril pada biakan patogen bakteri. Selanjutnya diambil suspensi bakteri tersebut sebanyak $100 \mu$ l, dituangkan dalam cawan Petri yang berisi medium NA, kemudian kertas saring steril diletakkan di tengah petri tersebut dan di tetesi P. flourescens P60 sebanyak $20 \mu 1$ (Agustiansyah et al., 2010; Astuti, 2008), dihitung daya hambat dengan rumus berikut.

$$
\mathrm{DH}=\frac{\mathrm{R}_{1}-\mathrm{R}_{2}}{\mathrm{R}_{1}} \times 100 \%
$$

dengan:

$\mathrm{R} 1=$ jari-jari pertumbuhan patogen ke arah tepi cawan Petri,

R2= jari-jari pertumbuhan patogen ke arah $P$. flourescens P60.

Pengujian P. flourescens P60 terhadap mutu patologis benih. Pengujian ini menggunakan metode blotter test. Pendeteksian patogen dilakukan dengan didesinfeksi dengan $\mathrm{NaOCl} 1 \%$ dan tanpa $\mathrm{NaOCl} 1 \%$. Benih diinkubasi pada suhu ruang dengan penyinaran NUV selama 12 jam terang, selanjutnya selama 24 jam pada suhu $-20^{\circ} \mathrm{C}$. Hari ketiga, benih kembali diinkubasi di bawah penyinaran NUV 12 jam terang dan 12 jam gelap secara bergantian sampai hari ketujuh (ISTA, 2008). Hari kedelapan, diamati, dan identifikasi patogen tular-benih dengan kunci identifikasi Pictorial atlas (Watanabe, 1994), dihitung persentase serangan patogen dengan rumus berikut.

Persentaseserangan $=\frac{\sum \text { benih terinfeksi }}{\sum \text { benih total }} \times 100 \%$ 
Pengujian P. flourescens P60 terhadap mutu fisiologis benih.

Daya berkecambah benih (DB). Daya berkecambah benih menggunakan metode uji kertas digulung di atas plastik (UKDDP). Daya berkecambah (DB) dihitung pada hari ke-7 sebagai hitungan I (KN I) dan hari ke-14 sebagai hitungan II (KN II) (ISTA, 2004; Wongvarodom \& Naulkong, 2006), dihitung persentase daya berkecambah (DB) dengan rumus berikut.

$$
\mathrm{DB}=\frac{\sum \mathrm{KNI}+\sum \mathrm{KNII}}{\sum \text { Benih yang ditanam }} \times 100 \%
$$

Berat kering kecambah (BKC). Kecambah normal yang berumur 14 HST dibersihkan dari bagian biji/kotiledon yang masih menempel kemudian dikeringkan dalam oven pada suhu $80^{\circ} \mathrm{C}$ selama 24 jam, selanjutnya dimasukkan dalam desikator selama \pm 30 menit dan ditimbang (ISTA, 2004), dihitung berat kering kecambah dengan rumus berikut.

$$
\mathrm{BKC}=\mathrm{K} 1-\mathrm{K} 0
$$

dengan:

$\mathrm{K} 1=$ Berat awal kecambah sebelum di oven,

$\mathrm{K} 0=$ Berat akhir kecambah setelah di oven .

Laju pertumbuhan kecambah (LPK). Laju pertumbuhan kecambah merupakan metode yang dikembangkan oleh Burris (1976 dalam Copeland \& McDonald, 2001). Laju pertumbuhan kecambah dihitung dengan rumus berikut.

$$
\mathrm{LPK}=\frac{\mathrm{BKKN}}{\sum \mathrm{KN}} \times 100 \%
$$

dengan:

BKKN = bobot kering kecambah normal,

$\mathrm{KN}=$ jumlah kecambah tidak normal yang dikeringkan dalam oven $60^{\circ} \mathrm{C}$ selama $3 \times 24$ jam.

Potensi tumbuh maksimum (PTM). Potensi tumbuh maksimum dihitung berdasarkan persentase benih yang mampu menjadi kecambah normal maupun tidak normal pada pengamatan hari terakhir (hari ke14) per jumlah benih yang ditanam (ISTA, 2004), dihitung persentase PTM dengan rumus berikut.

$$
\mathrm{PTM}=\frac{\sum \text { benih yang tumbuh }}{\sum \text { benih yang di tanam }} \times 100 \%
$$

Kecepatan tumbuh (KCT). $\quad$ M e n u r u t Sadjad (1993), Kecepatan tumbuh diukur dengan menghitung kecambah normal dengan rumus berikut.

$$
\mathrm{KCT}=\sum_{0}^{\mathrm{tn}} \frac{\mathrm{N}}{\mathrm{t}}
$$

dengan:

$\mathrm{N}=$ benih yang tumbuh,

$\mathrm{t}=$ waktu $(24$ jam $)$

Indeks Ketegaran (IK). Indeks ketegaran dihitung berdasarkan persentase kecambah normal pada hitungan pertama (7 HST) (ISTA, 2004), dihitung persentase indeks ketegaran (IK) dengan rumus berikut.

$$
\mathrm{IK}=\frac{\sum \mathrm{KN} \text { hitungan } \mathrm{I}}{\sum \text { benih ditanam }} \times 100 \%
$$

\section{Analisis kandungan kimia benih (Singleton \& Rossi, 1965; SNI, 1992).}

Analisis kadar air dengan metode oven (SNI 01-2891-1992 butir 5.1). Benih yang sudah dihancurkan sebanyak 1-2 g dimasukan ke dalam botol yang sudah di ketahui beratnya, dioven dengan suhu $105^{\circ}$ C selama 3 jam, didinginkan dalam desikator, dihitung kadar air dengan rumus berikut.

$$
\text { Kadar air }=\frac{\mathrm{W}}{\mathrm{W}_{1}} \times 100 \%
$$

dengan:

$\mathrm{W}=$ berat benih sebelum dikeringkan,

$\mathrm{W} 1=$ berat benih setelah dikeringkan.

Analisis Protein dengan metode Semimikro Kjedhal (SNI 01-2891-1992 butir 7.1). Benih sebanyak 0,51 g dimasukkan ke dalam labu Kjedhal 100 $\mathrm{ml}$, ditambahkan $2 \mathrm{~g}$ campuran selen dan $25 \mathrm{ml} \mathrm{H}_{2} \mathrm{SO}_{4}$ pekat, dipanaskan hingga mendidih. Sebanyak $5 \mathrm{ml}$ larutan diambil dan dimasukkan ke dalam alat penyuling,

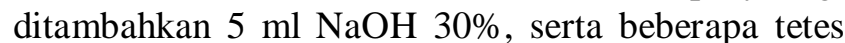
indikator PP. Disulingkan selama 10 menit dengan penampung $10 \mathrm{ml}$ larutan asam borat $2 \%$ yang telah dicampur indikator dan dititrasi dengan larutan HCL 0.01 $\mathrm{N}$, dikerjakan juga blanko. Dihitung kadar protein (KP) dengan rumus berikut.

$$
\mathrm{KP}=\frac{(\mathrm{V} 1-\mathrm{V} 2) \times \mathrm{N} \times 0.014 \times f k \times f p}{\mathrm{~W}}
$$


dengan:

$\mathrm{W}=$ berat benih,

$\mathrm{V} 1=$ volume $\mathrm{HCl} 0.01 \mathrm{~N}$ yang dipergunakan penitaran contoh,

$\mathrm{V} 2$ = volume $\mathrm{HCl}$ yang digunakan penitaran blanko,

$\mathrm{N}=$ normalitas blanko,

$\mathrm{fk}=$ kadar protein,

$\mathrm{fp}=$ faktor pengenceran.

Analisis lemak dengan metode hidrolisis (SNI 01-2891-1992 butir 8.2). Benih sebanyak 1-2 g dimasukkan ke dalam gelas piala, ditambahkan $30 \mathrm{ml}$ $\mathrm{HCl} 25 \%, 20 \mathrm{ml}$ air dan batu didih, dididihkan selama 15 menit, disaring dan dicuci dengan air panas, dikeringkan dan diekstrak dengan pelarut lemak selama 2-3 jam dengan temperatur kurang $80^{\circ} \mathrm{C}$, didinginkan, ditimbang dan dihitung kadar lemak (KL) dengan rumus berikut.

$$
\mathrm{KL}=\frac{\mathrm{W} 1-\mathrm{W} 2}{\mathrm{~W}}
$$

dengan:

$\mathrm{W}=$ berat benih,

$\mathrm{W} 2$ = berat lemak sesudah ekstraksi,

$\mathrm{W} 1$ = berat lemak sebelum ekstraksi.

Kadar abu (SNI 01-2891-1992 butir 6.1). Benih yang sudah dihancurkan sebanyak 2-3 g dimasukkan ke dalam cawan yang diketahui beratnya, diarangkan, diabukan dalam tanur listrik sampai pengabuan sempurna, didinginkan, ditimbang dan dihitung kadar abu (Kab) dengan rumus berikut.

$$
\mathrm{Kab}=\frac{\mathrm{W} 1-\mathrm{W} 2}{\mathrm{~W}}
$$

dengan:

$\mathrm{W}=$ berat benih sebelum diabukan

$\mathrm{W} 1=$ Berat benih dan cawan sesudah diabukan

$\mathrm{W} 2=$ Berat cawan kosong.

Analisis kadar karbohidrat (SNI 01-28911992). Kadar karbohidrat dilakukan secara by different, yaitu dihitung sebagai selisih 100 dikurangi kadar air, abu, protein, dan lemak.

Analisis fenol total metode Folin-Ciocalteu (Singleton \& Rossi, 1965). Sebanyak $0.1 \mathrm{ml}$ cairan benih dilarutkan dalam metanol (konsentrasi $1 \mathrm{mg}$ sampel $/ \mathrm{ml}$ ), diencerkan menjadi $1 \mathrm{ml}$ dengan akuades, ditambahkan $0.5 \mathrm{ml}$ reagen Folin Ciocalteu dan $2 \mathrm{ml}$ larutan $\mathrm{Na} 2 \mathrm{CO} 37.5 \%$, dihomogenkan dan dibiarkan selama 30 menit pada suhu $40^{\circ} \mathrm{C}$, diukur pada panjang gelombang $760 \mathrm{~nm}$, dihitung total fenol (TF) dengan rumus berikut.

dengan:

$$
\mathrm{TF}=\frac{\mathrm{fp} \times \text { nilai } \mathrm{X} \times 3,5 \mathrm{ml} \times 1}{\text { berat sampel }}
$$

$\mathrm{fp}=$ faktor pengenceran,

$\mathrm{X}=$ konsentrasi fenol.

Aplikasi $P$. flourescens $\mathbf{P 6 0}$ terhadap pertumbuhan bibit padi IR 64 di rumah kaca. Benih diperlakukan dengan P. flourescens P60 ditanam dalam polibag berisi tanah $300 \mathrm{~g}$ yang telah dipasteurkan, dipupuk dengan anjuran spesifik lokasi Kabupaten Cianjur. Setiap polibag ditanam lima butir benih padi IR 64 dan diulang 3x, diamati tinggi bibit, panjang akar, berat bibit basah, berat bibit kering, dan berat akar kering (Agustiansyah et al., 2010).

Analisis mikroba dalam medium tanah yang digunakan. Sebanyak $10 \mathrm{~g}$ tanah dimasukkan ke erlenmeyer $250 \mathrm{ml}$ yang berisi $90 \mathrm{ml}$ larutan $\mathrm{NaCl} 0,85 \%$, digojok 30 menit, didiamkan 10 menit, dilanjutkan pengenceran berseri hingga $10^{-7}$, diambil $0,1 \mathrm{ml}$ pada pengenceran seri $10^{-4}-10^{-7}$ untuk bakteri, $10^{-2}-10^{-5}$ untuk jamur, ditumbuhkan dalam cawan Petri medium NA untuk bakteri dan medium PDA dengan Streptomisin untuk jamur, duplo, diinkubasikan 3-4 hari untuk bakteri, dan 5-7 hari untuk jamur (Saraswati et al., 2007; Kartika, 2012).

Penghitungan kerapatan koloni akhir $P$. flourescens P60. Sebanyak $10 \mathrm{~g}$ tanah sekitar perakaran dimasukkan ke erlenmeyer $250 \mathrm{ml}$ yang berisi $90 \mathrm{ml}$ air steril, digojok 30 menit, didiamkan 10 menit, dilanjutkan dengan pengenceran berseri, diambil 0,1 ml, ditumbuhkan dalam cawan Petri yang berisi medium King's B, diinkubasi selama 48 jam pada suhu ruang. Koloni yang tumbuh dihitung kerapatannya, duplo (Saraswati et al., 2007; Kartika, 2012).

\section{Analisis IAA dalam $P$. flourescens $\mathbf{P 6 0}$.}

Analisis IAA secara kualitatif. Bakteri yang menghasilkan IAA di uji secara kualitatif dengan metode kolorimetri menggunakan reagen Salkowski (Gordon $\&$ Weber, 1951).

Analisis IAA secara kuantitatif. Analisis konsentrasi IAA dengan metode HPLC yaitu dengan mengambil $2 \mathrm{~mL}$ kultur cair bakteri di sentrifuge pada $12.000 \mathrm{rpm}$ selama 10 menit. Supernatan di ambil di injeksikan pada HPLC. Fase gerak adalah air : asetonitril 
(76 : $24 \mathrm{v} / \mathrm{v})$. Kolom yang di gunakan adalah C-18 reverse phase dengan detektor UV pada panjang gelombang $280 \mathrm{~nm}$, kecepatan alir $1 \mathrm{ml} /$ menit, suhu maksimum 85 ${ }^{\circ} \mathrm{C}$, suhu kolom $32,6^{\circ} \mathrm{C}$, volum injeksi $20 \mu \mathrm{L}$ dan tekanan 10, $9 \mathrm{MPa}$. Konsentrasi IAA dari sampel dihitung berdasarkan kurva standar dengan standar IAA murni (Tien et al.,1979; Lee, et al., 2004; Patil et al., 2011).

Analisis Data. Data yang diperoleh dianalisis sidik ragam (ANOVA) dengan menggunakan Statistical Analisys System (SAS 2003). Setiap perlakuan yang berpengaruh nyata dilakukan uji jarak berganda Duncan pada $\alpha=0,05$ (Mattjik \& Sumertajaya, 2006).

\section{HASIL DAN PEMBAHASAN}

Deteksi dan identifikasi patogen tular-benih padi IR 64. Hasil deteksi dan identifikasi patogen tular-benih pada padi IR 64 adalah Aspergillus flavus, Alternaria padwickii, Pseudomonas glumae, dan Pseudomonas syringae (Gambar 1).
Daya hambat $P$. flourescens $\mathbf{P 6 0}$ terhadap pertumbuhan koloni patogen in vitro. Pengujian $P$. flourescens P60 terhadap patogen dilakukan untuk melihat keefektifan $P$. flourescens P60 dalam menghambat patogen tular-benih. Secara umum daya hambat maupun zona hambat $P$. flourescens P60 terhadap patogen tidak berbeda nyata dengan daya hambat benomil, namun berbeda nyata terhadap $P$. syringae (Tabel 1).

Tabel 1 menunjukkan bahwa perlakuan $P$. flourescens $\mathrm{P} 60$ dan benomil tidak berpengaruh nyata terhadap daya hambat A. flavus, A. padwickii, dan zona hambat $P$. glumae, namun berpengaruh nyata terhadap zona hambat $P$. syringae. Hal ini menunjukkan bahwa aplikasi $P$. flourescesns tidak berbeda nyata dengan aplikasi benomil dalam menghambat $A$. flavus, $A$. padwickii dan $P$. glumae, namun berbeda secara nyata dalam menghambat $P$. syringae. Kemampuan agensia hayati $P$. flourescens P60 dalam menghambat jamur dan bakteri patogen dikarenakan adanya metabolit sekunder yang dihasilkan oleh $P$. flourescens P60 yaitu antibiotika dan senyawa siderofor (Soesanto et al., 2011).

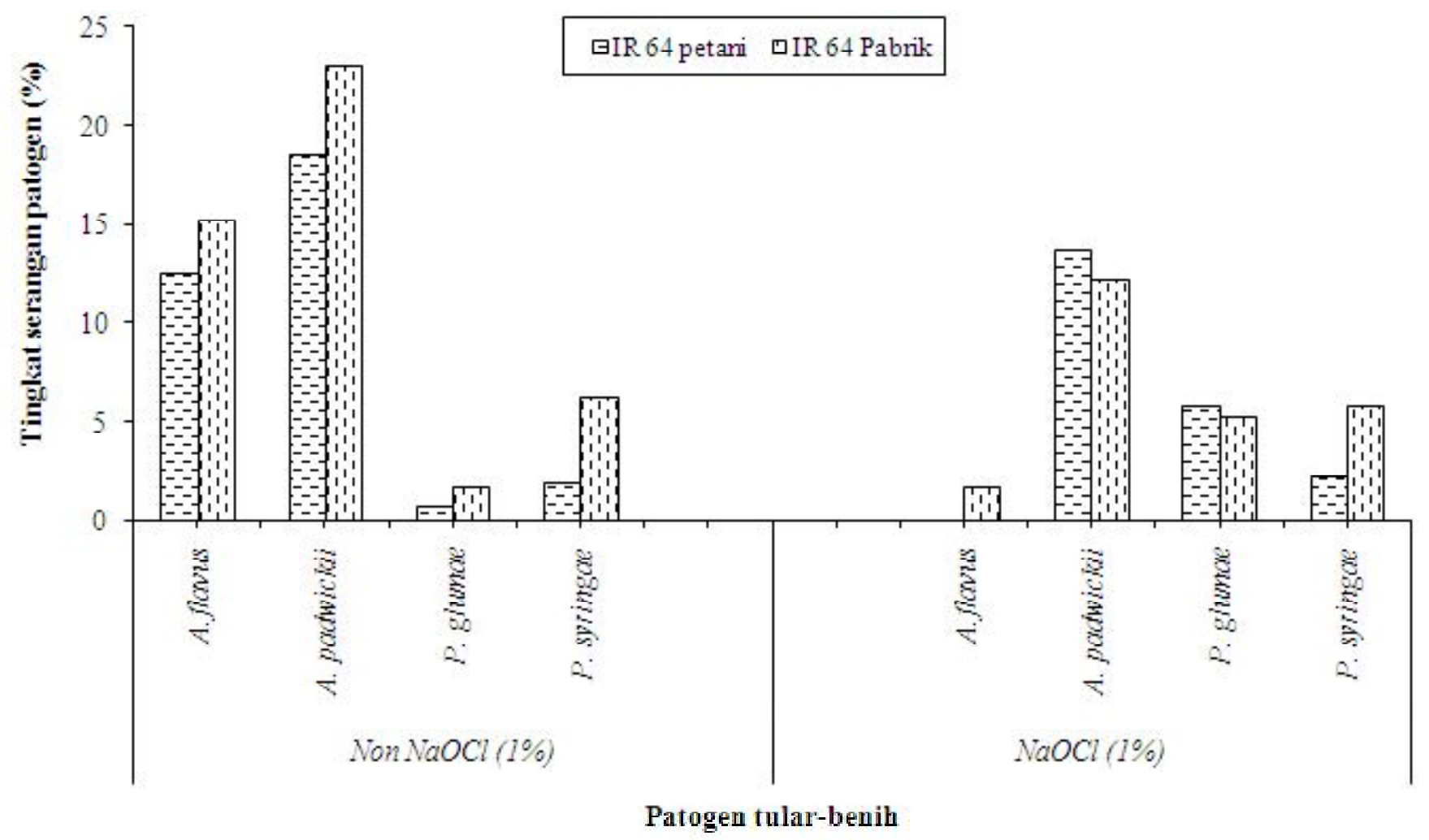

Gambar 1. Persentase serangan patogen tular benih padi IR 64 dari petani dan IR 64 dari pabrik. 
Tabel 1. Hasil pengujian perlakuan Pseudomonas flourescens P60 dan benomil terhadap pertumbuhan koloni patogen tular-benih

\begin{tabular}{|c|c|c|c|c|}
\hline \multirow{2}{*}{ Perlakuan } & \multicolumn{2}{|c|}{$\begin{array}{c}\text { Daya hambat terhadap jamur tular- } \\
\text { benih }(\%)\end{array}$} & \multicolumn{2}{|c|}{$\begin{array}{l}\text { Diameter hambatan terhadap bakteri tular- } \\
\text { benih (mm) }\end{array}$} \\
\hline & A. padwickii & A. flavus & P. syringae & P. glumae \\
\hline P. flourescens P60 & $23,92 \mathrm{a}$ & $32,79 \mathrm{a}$ & $15,67 \mathrm{a}$ & $14,33 \mathrm{a}$ \\
\hline Benomil & $17,65 \mathrm{a}$ & $34,43 \mathrm{a}$ & $12,33 \mathrm{~b}$ & $9,83 \mathrm{a}$ \\
\hline
\end{tabular}

Angka yang diikuti huruf yang sama dalam kolom yang sama menunjukkan tidak berbeda nyata menurut uji Duncan pada $\alpha=0,05$.

Tabel 2. Hasil sidik ragam tingkat serangan patogen tular-benih pada berbagai perlakuan pestisida (P), sumber benih (SB), dan desinfektan (D) terhadap kesehatan benih

\begin{tabular}{|c|c|c|c|c|c|c|c|}
\hline Peubah & $\mathrm{P}$ & SB & $\mathrm{D}$ & $\begin{array}{c}\text { Interaksi } \\
\mathrm{P} * \mathrm{SB}\end{array}$ & $\begin{array}{c}\text { Interaksi } \\
\mathrm{P} * \mathrm{D}\end{array}$ & $\begin{array}{l}\text { Interaksi } \\
\text { SB*D }\end{array}$ & $\begin{array}{l}\text { Interaksi } \\
\mathrm{P} * \mathrm{SB} * \mathrm{D}\end{array}$ \\
\hline
\end{tabular}

Tingkat serangan

$\begin{array}{lccccccc}\text { A. flavus } & \mathrm{n} & \mathrm{n} & \mathrm{n} & \text { tn } & \text { tn } & \text { th } & \text { tn } \\ \text { A. padwickii } & \mathrm{n} & \mathrm{n} & \mathrm{n} & \mathrm{n} & \text { n } & \mathrm{n} & \mathrm{n} \\ \text { P. } \text { glumae } & \mathrm{n} & \mathrm{n} & \mathrm{tn} & \text { tn } & \text { tn } & \text { th } & \text { tn } \\ \text { P. syringae } & \mathrm{n} & \mathrm{n} & \mathrm{n} & \text { tn } & \text { tn } & \text { tn } & \text { tn }\end{array}$

tn $=$ tidak nyata, $\mathrm{n}=$ nyata, $\mathrm{P}=P$. flourecens $\mathrm{P} 60$ dan Benomil, $\mathrm{SB}=\mathrm{IR} 64$ dari Petani dan Sertifikat, dan $\mathrm{D}=$ $\mathrm{NaOCl}$ dan Tanpa $\mathrm{NaOCl} 1 \%$.

\section{Pengaruh Pseudomonas flourescens P60 terhadap} mutu patologis benih. Pengujian $P$. flourescens P60 terhadap mutu patologis benih perlu dilakukan karena berkaitan dengan ada tidaknya patogen tular-benih, yang ditunjukkan dengan persentase tingkat serangan patogen. Hasil pengujian P. flourescens P60 terhadap mutu patologis ditunjukkan Tabel 2.

Tabel 2 menunjukkan pengaruh nyata pada tingkat serangan patogen A. flavus, A. padwickii, dan $P$. syringae pada perlakuan benomil, sumber benih dan desinfektan, namun tingkat serangan patogen $P$. glumae pada perlakuan desinfektan menunjukkan pengaruh tidak nyata. Hal ini dikarenakan, $P$. glumae merupakan patogen yang berada di dalam jaringan benih. P. glumae umumnya terdapat dalam jaringan dalam benih (biji padi) (Cottyn, 2002), sehingga ketika dilakukan desinfektan di permukaan benih, tidak meminimumkan tingkat serangan patogen tersebut. Disinfestasi ditujukan untuk mematikan jamur, bakteri, atau serangga yang berada di permukan benih (surface organism) tetapi belum menginfeksi permukan benih (Desai et al., 1997).

Pengaruh yang nyata antar perlakuan, yaitu $P$. flourescens P60 dan benomil terhadap tingkat serangan patogen, dikarenakan P. flourescens $\mathrm{P} 60$ memiliki antibiotik dan siderofor yang bersifat sebagai anti jamur dan anti bakteri (Soesanto et al., 2011). Sementara benomil, memiliki senyawa aktif karbendazim yang bersifat toksik dan fungisida berspektrum luas (Syahbirin et al., 2001). Sumber benih memberikan pengaruh yang nyata dikarenakan perbedaan perlakuan pada benih, yang benih IR 64 dari pabrik telah mengalami proses penyimpanan yang cukup lama dibandingkan dengan benih IR 64 dari petani tanpa proses penyimpanan sehingga lebih rentan diserang oleh patogen tular-benih.

Kombinasi perlakuan $P$. flourescens P60 dan benomil, sumber benih, dan desinfektan juga menunjukkan pengaruh nyata terhadap tingkat serangan A. padwickii. Hal ini dikarenakan A. padwickii merupakan patogen utama pada benih padi, yang dapat berada di dalam jaringan maupun permukaan benih sehingga ketika diperlakukan dengan P. flourescens P60 dan benomil sebagai anti jamur memberikan pengaruh yang nyata terhadap tingkat serangan tersebut. $A$. padwickii merupakan jamur lapangan, secara umum selain bersifat nekrotof terbawa sebagai kontaminan, juga berada dalam jaringan perikarp benih (Maude, 1996; Sumrahardi, 2000). Perlakuan P. flourescens P60 memiliki tingkat serangan patogen yang lebih kecil dan 
berbeda nyata dengan perlakuan akuades (Tabel 3). Hal ini menunjukkan P. flourescens P60 mampu menekan adanya patogen tular-benih.

Perlakuan $P$. flourescens P60 mampu menekan tingkat serangan patogen A. flavus, A. padwickii, $P$. syiringae, dan $P$. glumae, dikarenakan karakteristik biokimia yang dimiliki $P$. flourescens P60 seperti antibiotik dan siderofor (Soesanto et al., 2011). Dwivedi \& Johri (2003) melaporkan, antibiotika pyoluteorin (Plt), pyrrolnitrin (Prn), phenazine-1-carboxylic acid (PCA) and 2,4-di-acetylphloroglucinol (Phl) bersifat sebagai antijamur dan antibakteri.

\section{Pengaruh P. flourescens P60 terhadap mutu} fisiologis benih. Pengujian P. flourescens P60 terhadap mutu fisiologis ditujukkan untuk melihat sejauh mana pengaruh P. flourescens P60 terhadap mutu fisiologis. Hasil pengujian P. flourescens P60 terhadap komponen mutu fisiologis benih ditunjukkan Tabel 4 dan Tabel 5.
Tabel 4 dan Tabel 5 menunjukkan perlakuan $P$. flourescens $\mathrm{P} 60$ memberikan pengaruh yang tidak berbeda nyata dengan perlakuan benomil terhadap daya kecambah, potensi tumbuh maksimum, kecepatan kecambah tumbuh, dan indeks ketegaran, namun berbeda nyata terhadap berat kering kecambah dan laju pertumbuhan kecambah. Hasil perlakuan $P$. flourescens P60 dan benomil dengan hasil yang tidak berbeda nyata dengan perlakuan akuades (kontrol) terhadap kegigasan dan ketegaran benih, menunjukkan bahwa perlakuan P. flourescens $\mathrm{P} 60$ memiliki pengaruh yang sama dengan perlakuan akuades dan benomil. Daya kecambah di atas $80 \%$ menunjukkan P. flourescens P60 tidak bersifat toksik (racun) bagi benih. Raka et al. (2012) melaporkan, nilai variabel kegigasan total dan kegigasan berpotensi di atas $80 \%$ merupakan nilai yang sangat informatif bagi produsen benih. Menurut ISTA (2004), benih memiliki mutu fisiologis baik jika daya berkecambah di atas $80 \%$. Kemampuan suatu benih dalam berkecambah normal juga dipengaruhi oleh kandungan kimia benih.

Tabel 3. Tingkat serangan patogen tular-benih pada berbagai perlakuan

\begin{tabular}{lcccc}
\hline \multirow{2}{*}{ Perlakuan } & \multicolumn{4}{c}{ Tingkat serangan patogen tular-benih (\%) } \\
\cline { 2 - 5 } & A. flavus & A. padwickii & P. syringae & P. glumae \\
\hline P605 & $0,31 \mathrm{~b}$ & $8,69 \mathrm{~b}$ & $0,75 \mathrm{bc}$ & $0,87 \mathrm{bc}$ \\
P6015 & $0,25 \mathrm{~b}$ & $6,81 \mathrm{~b}$ & $1,31 \mathrm{~b}$ & $0,19 \mathrm{c}$ \\
P6025 & $0,19 \mathrm{~b}$ & $9,06 \mathrm{~b}$ & $1,37 \mathrm{bc}$ & $0,56 \mathrm{bc}$ \\
P6040 & $0,37 \mathrm{~b}$ & $8,75 \mathrm{~b}$ & $0,81 \mathrm{bc}$ & $1,19 \mathrm{ab}$ \\
Aqua15 & $7,25 \mathrm{a}$ & $16,37 \mathrm{a}$ & $4,06 \mathrm{a}$ & $2,37 \mathrm{a}$ \\
Beno5 & $0,19 \mathrm{~b}$ & $4,56 \mathrm{c}$ & $0,44 \mathrm{c}$ & $2,37 \mathrm{a}$ \\
NaOCl & $0,39 \mathrm{~b}$ & $6,37 \mathrm{~b}$ & $1,13 \mathrm{~b}$ & $1,21 \mathrm{a}$ \\
Tanpa NaOCl & $2,46 \mathrm{a}$ & $11,71 \mathrm{a}$ & $1,79 \mathrm{a}$ & $1,31 \mathrm{a}$ \\
\hline
\end{tabular}

Angka yang diikuti huruf yang sama dalam kolom yang sama menunjukkan tidak berbeda nyata menurut uji Duncan pada $\alpha=0,05$. P605 $=$ P. flourescens $\mathrm{P} 60$ perendaman 5 menit, P6015 $=$ P. flourescens $\mathrm{P} 60$ perendaman 15 menit, $\mathrm{P} 6025=$ P. flourescens $\mathrm{P} 60$ perendaman 25 menit, P6040 $=$. flourescens $\mathrm{P} 60$ perendaman 40 menit, Aqua 15 = akuades perendaman 15 menit, dan Beno5 = benomil perendaman 5 menit.

Tabel 4. Hasil sidik ragam komponen mutu fisiologis pada perlakuan pestisida

\begin{tabular}{lc}
\hline Peubah & Pestisida $(\mathrm{P})$ \\
\hline Daya berkecambah & tn \\
Berat kering kecambah & $\mathrm{n}$ \\
Laju pertumbuhan kecambah & $\mathrm{n}$ \\
Potensi tumbuh maksimum & tn \\
Kecepatan kecambah tumbuh & tn \\
Indeks ketegaran & tn \\
\hline
\end{tabular}

$\mathrm{tn}=$ tidak berbeda nyata, $\mathrm{n}=$ nyata ; biopestisida $=$ P. flourescens P60, pestisida kimia $=$ benomil . 
Tabel 5. Hasil pengujian mutu fisiologis pada berbagai perlakuan

\begin{tabular}{llllllc}
\hline \multirow{2}{*}{ Perlakuan } & \multicolumn{5}{c}{ Kegigasan benih } & \multicolumn{3}{c}{ Ketegaran benih } \\
\cline { 2 - 7 } & \multicolumn{1}{c}{ DB $(\%)$} & BKC $(\mathrm{g})$ & LPK $(\%)$ & PTM $(\%)$ & KCT $(\% / 24$ jam $)$ & IK (\%) \\
\cline { 2 - 7 } & $82,33 \mathrm{a}$ & $0,34 \mathrm{bc}$ & $82,17 \mathrm{abc}$ & $82,33 \mathrm{a}$ & $1,72 \mathrm{a}$ & $75,00 \mathrm{a}$ \\
P605 & $85,33 \mathrm{a}$ & $0,35 \mathrm{bc}$ & $81,00 \mathrm{bc}$ & $85,33 \mathrm{a}$ & $1,78 \mathrm{a}$ & $77,00 \mathrm{a}$ \\
P6015 & $81,67 \mathrm{a}$ & $0,34 \mathrm{bc}$ & $84,00 \mathrm{abc}$ & $81,67 \mathrm{a}$ & $1,70 \mathrm{a}$ & $77,67 \mathrm{a}$ \\
P6025 & $82,00 \mathrm{a}$ & $0,32 \mathrm{c}$ & $78,00 \mathrm{c}$ & $82,00 \mathrm{a}$ & $1,71 \mathrm{a}$ & $75,33 \mathrm{a}$ \\
P6040 & $82,00 \mathrm{a}$ & $0,36 \mathrm{ab}$ & $87,83 \mathrm{ab}$ & $82,00 \mathrm{a}$ & $1,71 \mathrm{a}$ & $78,00 \mathrm{a}$ \\
Aqua15 & $85,67 \mathrm{a}$ & $0,38 \mathrm{a}$ & $88,17 \mathrm{a}$ & $85,67 \mathrm{a}$ & $1,78 \mathrm{a}$ & $80,00 \mathrm{a}$ \\
Beno5 & &
\end{tabular}

Angka yang diikuti huruf yang sama dalam kolom yang sama menunjukkan tidak berbeda nyata menurut uji Duncan pada $\alpha=0,05$. P605 $=$ P. flourescens $\mathrm{P} 60$ perendaman 5 menit, $\mathrm{P} 6015=\mathrm{P} 60$ perendaman 15 menit, P6025 = P60 perendaman 25 menit, P6040 = P60 perendaman 40 menit, Aqua15 = akuades perendaman 15 menit, Beno5 = benomil perendaman 5 menit, $\mathrm{DB}=$ daya berkecambah, $\mathrm{BKC}=$ berat kering kecambah, $\mathrm{LPK}=$ laju pertumbuhan kecambah, $\mathrm{PTM}=$ potensi tumbuh maksimum, $\mathrm{KCT}=$ kecepatan kecambah tumbuh, dan IK = indeks ketegaran .

Tabel 6. Hasil analisis kandungan kimia benih setelah perlakuan Pseudomonas flourescens P60

\begin{tabular}{lccc}
\hline \multirow{2}{*}{ Perlakuan } & \multicolumn{3}{c}{ Kandungan kimia benih } \\
\cline { 2 - 4 } & Protein $(\%)$ & Karbohidrat total $(\%)$ & Fenol total $(\mathrm{ppm})$ \\
\hline Benih IR 64 dari Petani & & & \\
Akuades & 6,80 & 83,99 & 0,40 \\
P6025 & 5,49 & 87,00 & 0,43 \\
P6015 & 6,57 & 85,76 & 0,44 \\
\hline Benih IR 64 dari Pabrik & & & \\
Akuades & 8,35 & 84,84 & 0,22 \\
P6025 & 7,31 & 86,27 & 0,18 \\
P6015 & 8,71 & 84,74 & 0,20 \\
\hline
\end{tabular}

P6025 = P. flourescens P60 perendaman 25 menit dan P6015 = P. flourescens P60 perendaman 15 menit. Sampel benih yang dianalisis pada kondisi kering udara.

Analisis kandungan kimia benih setelah perlakuan P. flourescens P60. Analisis kandungan benih setelah perlakuan $P$. flourescens P60 ditujukan untuk melihat sejauh mana pengaruh aplikasi $P$. flourescens P60 terhadap kandungan kimia benih yang meliputi karbohidrat, protein, dan fenol total. Hasil analisis kandungan kimia benih ditunjukkan Tabel 6 .

Perlakuan P. flourescens P60 dengan waktu perendaman 25 menit pada benih IR 64 dari petani dan benih bersertifikat memiliki kandungan protein paling rendah dibandingkan waktu perendaman 15 menit dan akuades. Hal ini dikarenakan P. flourescens P60 menghasilkan metabolit sekunder berupa enzim protease dan hidrolisis gelatin. Uji hidrolisis gelatin berkaitan dengan kemampuan menghidrolisis protein oleh enzim protease, sehingga kandungan protein benih pada perlakuan $P$. flourescens $\mathrm{P} 60$ lebih rendah dibandingkan perlakuan akuades (Tabel 6).

Kandungan karbohidrat total secara umum pada perlakuan Pseudomonas flourescens P60 menunjukkan kandungan karbohidrat total lebih tinggi dibandingkan perlakuan akuades (kontrol). Hal ini menunjukkan adanya aktivitas hidrolisis pati $P$. flourescens P60. Enzim hidrolisis pati (amilase) memecah pati menjadi komponen yang lebih sederhana seperti glukosa (Lestari et al., 2001; Richana et al.,1999). Sementara terhadap total fenol, menunjukkan kandungan fenol total pada benih IR 64 dari petani memiliki kandungan yang lebih tinggi dibandingkan benih IR 64 dari pabrik (Tabel 6). Hal ini diduga $P$. flourescens P60 memberikan tambahan 
fenol pada benih IR 64 dari Petani. Bangera \& Thomashaw (1996) melaporkan, antibiotik 2,4 diacetylphloroglucinol merupakan molekul fenol yang diproduksi $P$. flourescens. Kandungan karbohidrat dan total fenol pada benih setelah perlakuan $P$. flourescens P60 tidak menghambat perkecambahan dikarenakan benih mampu berkecambah normal dengan daya kecambah di atas $80 \%$, sehingga diperlukan pengujian P. flourescens P60 terhadap pertumbuhan bibit.
Pengujian aplikasi $P$. flourescens $\mathbf{P 6 0}$ terhadap pertumbuhan bibit di rumah kaca. Pengujian aplikasi $P$. flourescens selanjutnya adalah pengujian terhadap pertumbuhan bibit di rumah kaca selama 21 HST ditunjukkan Tabel 7 dan Tabel 8.

Tabel 7 dan Tabel 8 menunjukkan perlakuan $P$. flourescens $\mathrm{P} 60$, dan benomil menunjukkan pengaruh yang berbeda nyata terhadap berat akar kering dan berat bibit basah, namun tidak berbeda nyata terhadap tinggi

Tabel 7. Hasil sidik ragam komponen pertumbuhan bibit pada berbagai perlakuan pestisida(P) dan sumber benih (SB) di rumah kaca selama 21 HST

\begin{tabular}{lccc}
\hline Peubah & Pestisida $(\mathrm{P})$ & Sumber benih $(\mathrm{SB})$ & Interaksi $(\mathrm{P} * \mathrm{SB})$ \\
\hline Tinggi bibit & tn & $\mathrm{n}$ & tn \\
Panjang akar & tn & tn & tn \\
Berat bibit kering & tn & tn & tn \\
Berat akar kering & $\mathrm{n}$ & tn & tn \\
Berat bibit basah & $\mathrm{n}$ & tn & tn \\
\hline
\end{tabular}

$\mathrm{tn}=$ tidak nyata, $\mathrm{n}=$ nyata, pestisida $=$ biopestisida $P$. flourescens $\mathrm{P} 60$, pestisida kimia Benomil, dan SB = IR 64 dari Petani dan IR 64 bersertifikat.

Tabel 8. Hasil pengujian terhadap pertumbuhan bibit pada berbagai perlakuan selama 21 HST di rumah kaca

\begin{tabular}{llllll}
\hline \multirow{2}{*}{ Perlakuan } & \multicolumn{5}{c}{ Komponen pertumbuhan bibit } \\
\cline { 2 - 6 } & TB $(\mathrm{cm})$ & PA $(\mathrm{cm})$ & BBB $(\mathrm{g})$ & BBK $(\mathrm{g})$ & BAK $(\mathrm{g})$ \\
\hline P6015 & $32,81 \mathrm{ab}$ & $12,36 \mathrm{a}$ & $3,99 \mathrm{a}$ & $0,72 \mathrm{ab}$ & $0,16 \mathrm{~b}$ \\
P6025 & $33,94 \mathrm{a}$ & $12,85 \mathrm{a}$ & $4,22 \mathrm{a}$ & $0,78 \mathrm{a}$ & $0,17 \mathrm{a}$ \\
Aqua15 & $32,11 \mathrm{~b}$ & $11,98 \mathrm{a}$ & $3,06 \mathrm{~b}$ & $0,66 \mathrm{~b}$ & $0,15 \mathrm{~b}$ \\
Beno5 & $32,49 \mathrm{ab}$ & $12,25 \mathrm{a}$ & $3,21 \mathrm{~b}$ & $0,68 \mathrm{ab}$ & $0,14 \mathrm{~b}$ \\
\hline
\end{tabular}

Angka yang diikuti huruf yang sama dalam kolom yang sama menunjukkan tidak berbeda nyata menurut uji Duncan pada $\alpha=0,05$. P6015 $=$ P. flourescensP60 perendaman 15 menit, P6025 $=$ P. flourescens $\mathrm{P} 60$ perendaman 25 menit, Aqua $15=$ akuades perendaman 15 menit, Beno5 $=$ benomil perendaman 5 menit, $\mathrm{TB}=$ tinggi bibit, $\mathrm{PA}=$ panjang akar, $\mathrm{BBB}=$ berat bibit basah, $\mathrm{BAK}=$ berat bibit kering, dan $\mathrm{BAK}=$ berat akar kering.

Tabel 9. Peningkatan pertumbuhan bibit tanaman padi

\begin{tabular}{lccccc}
\hline \multirow{2}{*}{ Perlakuan } & \multicolumn{5}{c}{ Peningkatan pertumbuhan bibit $(\%)$} \\
\cline { 2 - 6 } & TB $(\mathrm{cm})$ & PA $(\mathrm{cm})$ & BBB $(\mathrm{g})$ & BBK $(\mathrm{g})$ & BAK $(\mathrm{g})$ \\
\hline P6015 & 2,18 & 3,17 & 30,39 & 9,09 & 6,67 \\
P6025 & 5,70 & 7,26 & 38,24 & 18,18 & 13,33 \\
Beno5 & 1,18 & 2,25 & 4,90 & 3,03 & $-6,67$ \\
\hline
\end{tabular}

Angka positif (+) menunjukkan adanya peningkatan, sedangkan angka negatif (-) menunjukkan adanya penurunan jika dibandingkan dengan perlakuan akuades. $\mathrm{P} 6015=P$. flourescens $\mathrm{P} 60$ perendaman 15 menit, $\mathrm{P} 6025=P$. flourescens $\mathrm{P} 60$ perendaman 25 menit, Beno5 = benomil perendaman 5 menit, $\mathrm{TB}=$ tinggi bibit, $\mathrm{PA}=$ panjang akar, $\mathrm{BBB}=$ berat bibit basah, $\mathrm{BAK}=$ berat bibit kering, dan $\mathrm{BAK}=$ berat akar kering. 
bibit, panjang akar, dan berat bibit kering, yang perlakuan P. flourescens P60 memiliki nilai yang lebih besar masing-masing sebesar $0,16 \mathrm{~g}$ dan 3,99 g pada waktu perendaman 15 menit dan $0,17 \mathrm{~g}$ dan $4,22 \mathrm{~g}$ pada waktu perendaman 25 menit. Hal ini disebabkan karakteristik $P$. flourescens menghasilkan hormon tumbuh IAA dan melarutkan fosfat.

Secara umum perlakuan P. flourescens P60 meningkatkan komponen pertumbuhan bibit tanaman padi di rumah kaca (Tabel 9). Peningkatan komponen pertumbuhan bibit diantaranya dikarenakan formula aplikasi $P$. flourescens P60 memiliki kepadatan koloni awal dan akhir yang tinggi $10^{11} \mathrm{upk} / \mathrm{ml}$ (Tabel 10), $P$. flourescens $\mathrm{P} 60$ merupakan mikroba pelarut fosfat (Gambar 2), dan produksi IAA oleh P. flourescens P60 (Tabel 11), selain itu juga ditemukan mikroba lain pada medium tanah yang digunakan ketika dilakukan analisis mikroba awal pada tanah yang digunakan sebelum aplikasi P. flourescens P60. Mikroba yang ditemukan tersebut bersifat menguntungkan karena tidak bersifat patogenik. Mikroba yang ditemukan yaitu Pseudomonas sp. dan Trichoderma sp. Mikroba tersebut diduga bersifat secara sinergis dengan P. flourescens P60.

Kerapatan koloni Pseudomonas flourescens P60 saat aplikasi sebesar $1,79 \times 10^{11} \mathrm{upk} / \mathrm{ml}$ secara umum mengalami penurunan di kerapatan koloni akhir, namun terjadi peningkatan di kerapatan koloni akhir dengan perlakuan perendaman P. flourescens P60 selama 20 menit pada sumber benih IR 64 dari pabrik. Salah satu penyebab terjadinya penurunan kerapatan koloni adalah kompetisi. Elad \& Chet (1987) melaporkan, mekanisme pengendalian biologi umumnya meliputi kompetisi. Sementara peningkatan kerapatan koloni dikarenakan suhu dan $\mathrm{pH}$ tanah yang mendukung

Tabel 10. Kerapatan koloni awal dan akhir Pseudomonas flourescens P60 pada bibit tanaman padi 21 HST

\begin{tabular}{llcc}
\hline \multirow{2}{*}{ Perlakuan } & Sumber benih & \multicolumn{2}{c}{ Jumlah koloni $P$. flourescens P60 $(\mathrm{upk} / \mathrm{ml})$} \\
\cline { 2 - 4 } & IR 64 dari petani & $1,79 \times 10^{11}$ & akhir \\
\hline \multirow{2}{*}{ P6015 } & IR 64 dari pabrik & $1,79 \times 10^{11}$ & $1,47 \times 10^{11}$ \\
\multirow{2}{*}{ P6025 } & IR 64 dari petani & $1,79 \times 10^{11}$ & $1,48 \times 10^{11}$ \\
& IR 64 dari pabrik & $1,79 \times 10^{11}$ & $1,59 \times 10^{11}$ \\
& & $1,87 \times 10^{11}$ \\
\hline
\end{tabular}

P6015 $=$ P. flourescens $\mathrm{P} 60$ perendaman 15 menit, P6025 $=$ P. flourecens $\mathrm{P} 60$ perendaman 25 menit, HST $=$ hari setelah tanam. Tanah yang di gunakan adalah tanah di sekitar perakaran bibit padi.

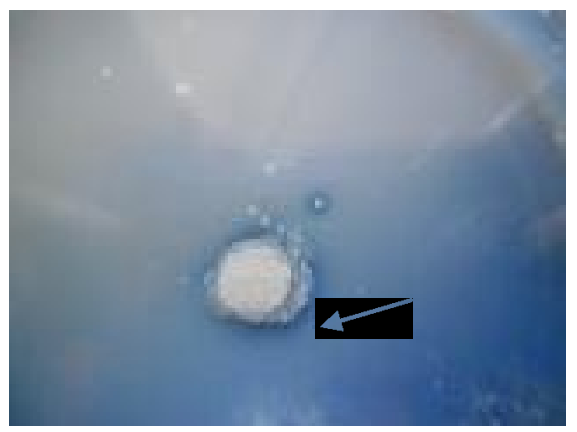

Gambar 2. Pseudomonas flourescens P60 sebagai mikroba pelarut fosfat (MPF). Tanda panah menunjukkan zona bening pelarutan fosfat pada medium Pikovskaya.

Tabel 11. Hasil analisis IAA Pseudomonas flourescens P60 menggunakan metode High Performance Liquid Chromatography (HPLC)

\begin{tabular}{lc}
\hline Sampel Pseudomonas flourescens P60 & Kandungan IAA (ppm) \\
\hline Original (formula asli) & 2,97 \\
Pengenceran ke-8 (Formula aplikasi) & 2,48 \\
\hline
\end{tabular}

Pengencer yang digunakan adalah larutan fisiologis $\mathrm{NaCl} 0,85 \%$. 
pertumbuhan $P$. flourescens P60, masing-masing sebesar $26,54^{\circ} \mathrm{C}$ dan 6,58. Rhodesm (1959) melaporkan, P. flourescens tumbuh pada suhu $12-30^{\circ} \mathrm{C}$ dan tidak dapat tumbuh pada kondisi pH kurang dari 4,5. Kerapatan koloni memengaruhi produksi IAA yang dihasilkan oleh $P$. flourescens P60, semakin tinggi kerapatan koloni maka semakin besar kandungan IAA. Hal ini terlihat pada sampel pengenceran ke-8 (formula aplikasi) memiliki kandungan IAA yang lebih kecil dibandingkan sampel asli (tanpa pengenceran) (Tabel $11)$.

\section{SIMPULAN}

Patogen tular-benih padi IR 64 baik dari petani maupun pabrik menunjukkan adanya Aspergillus flavus, Alternaria padwickii, Pseudomonas glumae, dan Pseudomonas syringae. Pseudomonas flourescens P60 memiliki pengaruh yang sama dengan benomil dalam menghambat pertumbuhan koloni Alternaria padwickii, Aspergillus flavus, dan P. glumae in vitro. Pengujian $P$. flourescens P60 terhadap mutu patologis benih menunjukkan persentase tingkat serangan patogen tular-benih lebih kecil dan berbeda dengan akuades, namun tidak berbeda dengan benomil. Sementara terhadap mutu fisiologis benih menunjukkan $P$. flourescens P60 memiliki pengaruh yang sama dengan perlakuan benomil dan akuades, serta $P$. flourescens P60 mampu mempertahankan mutu fisiologis dengan daya kecambah diatas $80 \%$. Pengujian Pseudomonas flourescens P60 waktu perendaman 15 menit dan 25 menit terhadap pertumbuhan bibit padi di rumah kaca memiliki pengaruh yang sama dengan akuades dan benomil terhadap tinggi bibit, panjang akar, dan berat bibit kering. Namun berbeda terhadap berat bibit basah dan berat akar kering pada P. flourescens P60 perendaman selama 25 menit.

\section{DAFTAR PUSTAKA}

Agarwal VK \& James BS. 2000. Principles of Seed Pathology. Vol. II. CRC Press. Florida.

Agustiansyah S, Ilyas, Sudarsono, \& Machmud M. 2010. Pengaruh perlakuan benih secara hayati pada benih padi terinfeksi Xanthomonas oryzae pv. oryzae terhadap mutu benih dan pertumbuhan bibit. J. Agronomi Indones. 38(3):185-191.

Astuti RI. 2008. Analisis Karakter Pseudomonas sp. sebagai agen Pemacu Pertumbuhan Tanaman dan Biokontrol Fungi Patogen. Tesis. IPB. Bogor. (tidak dipublikasikan).
Bangera MG \& Thomashaw LS. 1996. Characterization of a genomic locus required for synthesis of the antibiotic 2,4diacetylphloroglucinol by the biological control agent Pseudomonas flourescens Q2-87. PlantMicrobe Interaction 9: 83-90.

Copeland LO \& McDonald MB. 2001. Principle of Seed Science and Technology. 4th ed. Kluwer Academic Publisher. Massachusetts.

Cottyn B. 2002. Bacteria associated with rice seed from Philippine farmers fields. Tesis. University of Ghent. Los Banos, Laguna. http:// dspace.irri.org:8080/dspace/bitstream/123456789/ 446/1/CDPDF2002.Cottyn,B.pdf. Diakses tgl 5 Maret 2013.

Desai, BB, Kotecha PM, \& Salunkhe DK. 1997. Seeds Handbook: Biology, Production, Processing, and Storage. Marcel Dekkerm, New York.

Dwivedi D \& Johri BN. 2003. Antifungals from Flourescent Pseudomonads : Biosynthesis and regulation. Curr. Sci. 85(12): 1693-1703.

Elad Y \& Chet I. 1987. Possible role of competition for nutrients in biocontrol of Pythium damping-off by bacteria. Phytopathol.77: 190-195.

Ezra D, Hess WM, \& Strobel GA. 2004. New endophytic isolates of Muscodor albus, a volatileantibiotic-producing fungus. Microbiology. 150: 4023-4031. DOI 10.1099/mic.0.27334-0.

Gordon, SA \& Weber RP. 1951. Colorimetric estimation of indoleacetic acid. Plant Physiol. 26: 192-195.

Hadi S, Budiarti T, \& Haryadi. 2005. Studi komersialisasi benih padi sawah varietas unggul. Buletin Agronomi. 33(1): 12-18.

International Seed Testing Association (ISTA). 2004. International Rules for Seed Testing. Zurich. International Seed testing Association.

International Seed Testing Association (ISTA). 2008. International Rules for Seed Testing, Annexe to Chapter 7: Seed Health Testing Methods. Bassersdorf, Switzerland.

Kartika A. 2012. Teknik Eksplorasi dan Pengembangan Bakteri Pseudomonas flourescens.http:// www.laboratoriumphpbanyumas.com/isiwebsite/ A G E N S I A \% 20 H A Y A T I / eksplorasi\%20Pseudomonas\%20flouresens.pdf. Diakses tgl 24 Juni 2012. 
Lee S, Flores-Encarnaclon M, Contreras-Zentalla M, Garcia-Flores L, Escamilla JE, \& Kennedy C. 2004. Indole-3-acetic acid biosynthesis is deficient in Gluconacetobacter diazotrophicus strains with mutations in cytochrom biogenesis genes. Journal Bacteriology. 186 (16): 53845391.

Lestari P, Darwis AA, Syams I, Richana N \& Damardjati DS. 2001. Anailsis gula reduksi hasil hidrolisis enzimatik pati ubi kayu oleh a-Amilase Termostabil dan Bacillus stearothermophilus T1112. J. Mikrobiol. Indones. 6(1): 23-26

Mattjik AA \& Sumertajaya IM. 2006. Perancangan Percoban, dengan Aplikasi SAS dan Minitab. IPB Press. Bogor.

Maude RB. 1996. Seedborne Diseases and Their Control, Principles and Practice. Horticulture Research International. Cambrige. CAB International.

Patil NB, Gajbhiye M, Ahiwale SS, Gunjal AB, \& Kapadnis BP. 2011. Optimization of Indole 3acetic acid (IAA) production by Acetobacter diazotrophicus $\mathrm{L} 1$ isolated from sugarcane. $J$. Environ. Sci. 2(1): 295-302.

Raka, IGN, Astiningsih AAM, Nyana IDN, \& Siadi IK. 2012. Pengaruh dry heat treatment terhadap daya simpan benih cabai rawit (Capsicum frutescens L.). J. Agric. Sci. and Biotechnol. 1(1): 1-11.

Rhodesm E. 1959. The characterization of Pseudomonas fluorescens gen. Microbiol. 21:221-265.

Richana NGM, Yusuf, P. Lestari, \& Damardjati DS. 1999. Perilaku kultivasi isolat bakteri termofil penghasil $\alpha$-amilase. J. Mikrobiol. Indon. 4(2): 35-39.

Sadjad. 1993. Dari Benih kepada Benih. Gasindo. Jakarta.

Santoso SE, Soesanto L, \& Haryanto TAD. 2007. Penekanan hayati penyakit moler pada bawang merah dengan Trichoderma harzianum, Trichoderma koningii dan Pseudomonas flourescens P60. J. HPT Tropika. 7(1): 53-61.
Saraswati R, Husen E, \& Simanungkalit RDM. 2007. Metode Analisis Biologi Tanah. Balai Besar Penelitian dan Pengembangan Sumberdaya Lahan Pertanian. Bogor.

Singleton VL \& Rossi JA Jr. 1965. Colorunetry of total phenolics with phosphomolybdic-phosphotungstic acid reagents. American Journal Enology Viticulture. 16: 144-158.

Standar Nasional Indonesia (SNI). 1992. Cara uji makanan dan minuman. SNI 01-2891-1992. Badan Standarisasi Nasional.

Soesanto L, Mugiastuti E, \& Rahayuniati RF. 2011. Biochemichal characteristic of Pseudomonas flourescens P60. J. Biotechnol. and Biodiver. 2: 19-26.

Sumrahardi A. 2000. Identifikasi fungi yang berasosiasi dengan benih Acacia crassicarpa A. Cunn ex Benth sesat setelah panen dan setelah penyimpanan. Skripsi. IPB. Bogor. (tidak dipublikasikan).

Sutopo L. 1993. Teknologi Benih. PT Raja Gafindo Persada. Jakarta.

Syahbirin G, Purnama H, \& Prijono D. 2001. Residu pestisida pada tiga jenis buah impor. Buletin kimia. 1: 113-118.

Tien TM, Gaskins MH, \& Hubbel DH. 1979. Plant growth subtances produced by Azospirillum brasilense and their effect on the growth of pearl millet (Pennisetum americanum L.). Appl. Environ. Microbiol. 37(5): 1016-1024.

Turechek WW \& Stevenso KL. 1998. Effects of host resistance, temperature, leaf wetness, and leaf age on infection and lesion development of pecan scab. Phytopathol. 88: 1294-1301.

Watanabe T. 1994. Pictorial Atlas of Soil And Seed Fungi, Morphologies of Cultured Fungi and Key to Spesies. CRC Press, Inc., Florida.

Wongvarodom V \& Naulkong S. 2006. Responses of bambara goundnut seed to accelerated aging. Nat. Sci. 40: 848-853. 